\title{
BUSH FALLOW AND COWPEA CROP USE AS PRECEDENT AND ORGANIC SOURCES OF NUTRIENTS FOR RICE CULTIVATION ON ACIDIC PLINTHOSOL OF CENTRAL BENIN IN WEST AFRICA
}

\author{
ASSIGBE P. ${ }^{1}$, KONE B. ${ }^{2}$, BOGNONPKE J.P. ${ }^{3}$, TOURE A. ${ }^{4}$, HUAT J. ${ }^{4,5}$ AND YAO-KOUAME A. ${ }^{2}$ \\ IInstitiut National des Recherches Agricoles du Benin, B.P. 226 Bohicon, Benin. \\ ${ }^{2}$ Felix Houphouet Boigny University, Cocody, soil sciences department,Abidjan, Côte d'Ivoire. \\ ${ }^{3}$ Nagui Abrogba University, Department of plant biology and improvement, Abidjan, Côte d'Ivoire. \\ ${ }^{4}$ Africa Rice Center (WARDA), Cotonou. 01 BP 2031 Cotonou, Benin. \\ ${ }^{5}$ CIRAD, UPR Hortsys, F-34398, Montpellier Cedex 05, France. \\ *Corresponding Author: Email- kbrahima@hotmail.com
}

Received: October 19, 2012; Accepted: December 06, 2012

\begin{abstract}
Tropical soils have low fertility and chemical fertilizers are not affordable for most of the farmers, especially in West Africa. The development of low cost technologies for amending agricultural soils in this environment is needed. Biological and organic fertilizers were tested in 20 farmers' fields in central Benin for rainfed rice production on acidic plinthosol under monomodal rainfall pattern conditions. Short time matured cowpea and native grass fallow were preceding NERICA1 and Ina Okpè rice cultivars that are interspecific (Oryza glaberrima $\times$ Oryza sativa) and local varieties respectively. Cowpea and bush residues were incorporated into soil before rice seeding. Soil nutrients (C,N,K, $\mathrm{Ca}$ and $\mathrm{Zn}$ ) contents were significantly depleted whereas null balance was observed for soil available-P content. An increased of soil content in $\mathrm{Fe}\left(>130 \mathrm{mg} \mathrm{kg}^{-1}\right)$ was significantly observed in all the treatments. Highest yield of $1.6 \mathrm{tha}^{-1}$ was recorded in the treatment composed of cowpea and NERICA1. The study technology was deemed suitable in deficient-P acid soil whereas the land foot slope position was excluded to avoid potential increasing of $\mathrm{Fe}$ content (iron toxicity of rice) in soil of the subsequent lowland. Minimum chemical fertilizer was required for improving rainfed rice cultivation on plinthosol in monomodal rainfall pattern ecology.
\end{abstract}

Keywords- Biology Nitrogen Fixation, organic matter, fertilizer, rice, grain legume crop

Citation: Assigbe P., et al (2012) Bush Fallow and Cowpea Crop Use as Precedent and Organic Sources of Nutrients for Rice Cultivation on Acidic Plinthosol of Central Benin in West Africa. International Journal of Agriculture Sciences, ISSN: 0975-3710 \& E-ISSN: 0975-9107, Volume 4, Issue 8, pp-320-324.

Copyright: Copyright@2012 Assigbe P., et al. This is an open-access article distributed under the terms of the Creative Commons Attribution License, which permits unrestricted use, distribution and reproduction in any medium, provided the original author and source are credited.

\section{Introduction}

Soil nutrients depletion is among the major threats of crop production in Africa. In West Africa, because of land-use intensification and limited use of nutrient inputs, the fragile upland rice production systems contributing to a third of the total rice production, are experiencing intense soil degradation, nutrient depletion and low rice productivity [6]. Thus, rice yields in the upland production systems are seldom above $1 \mathrm{tha}^{-1}$ despite the reported potential yield of up to $4 \mathrm{tha}^{-1}$ [20]. A number of solutions have been proposed to address this declining of productivity.

Becker and Johnson [4,5] reported that the use of N2-fixing legumes including Mucuna spp., Stylosanthes guianensis, Canavalia ensiformis grown as preceding fallow cover crops increased upland rice productivity and suppressed weed growth under intensified land use in Côte d'Ivoire (West Africa). But this technology was not widely adopted by farmers. Farmers in West Africa are often reluctant to adopt legume cover crops that are not for human consump- tion or without a direct economic gain, in spite of the benefits for restoring soil fertility [31]. However, the grain legumes are infinitely more adoptable when integrated into cereal-based systems [25] for household food security and cash income. Somado, et al. [27] proposed the combined use of legume cover crops and sparinglysoluble indigenous phosphate rock as a low-cost technology to increase the supply of both $\mathrm{N}$ and $\mathrm{P}$ and enhance upland rice productivity on acid soils in Côte d'lvoire (West Africa). However, phosphate rock has a limited availability in West african countries meanwhile, grain legume crops can fix atmospheric- $\mathrm{N}_{2}$ and their residues can also enrich soil in nutrient by $38.9 \mathrm{~g} \mathrm{~N} \mathrm{~kg}^{-1}, 4 \mathrm{~g} \mathrm{P} \mathrm{kg}^{-1}$, and $21 \mathrm{~g} \mathrm{~K} \mathrm{~kg}^{-1}$ only from the leaf dry matter as observed for cowpea [1]. Therefore, legume as preceding crop to upland rice and organic source of nutrients after incorporation can improve soil fertility and upland rice yield. However, unlike the maize-based systems, the contribution of cowpea to upland rice-based systems has not been extensively studied in West Africa [21]. 
Yet, the occurrence of NERICAs (New Rice for Africa), the interspecific rice varieties released by Africa Rice Center can be more adapted to such practice of fertility strategy. In fact, interspecifics were known to be low-management rice type, adequate for resource-limited small holder $[10,16]$.

The actual study was initiated in Benin for the cropping of NERICA1 and a traditional cultivar after cowpea cropping and the growth of native grass fallow. The objective was to identify the effects of cowpea growth and its residues on soil fertility and rice yield in legume-rice based system without chemical fertilizer compared to native bush effects.

\section{Material and Methods}

\section{Experiment Site}

On-farm experiments were conducted in farmers' field and by farmers in the area of Glazoué, a mountainous area in the Centre Benin (West Africa). It is a Guinea savanna zone characterized by a degraded wood savanna. The rainfall pattern was monomodal with an annual average of $918.9 \mathrm{~mm}$ in 2001 and $1089.9 \mathrm{~mm}$ in 2002. Ten farmers were concerned in each selected site [Dassa- $\left(7^{\circ} 45^{\prime} 00^{\prime \prime} \mathrm{N}\right.$,

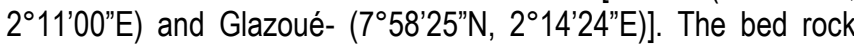
was granite gneiss with a plinthosol as dominant soil of the plateau. It was a sandy loamly soil, acidic and poor in organic carbone, total nitrogen and available $P$ in the $0-20 \mathrm{~cm}$ depth. But, it has a suitable content of $\mathrm{Ca}, \mathrm{Mg}$ and $\mathrm{K}$ [Table-1].

Table 1- Soil physico-chemical characteristics in the 0-20 cm depth before the experiment

\begin{tabular}{|c|c|c|c|c|}
\hline & Mean & SD & Minimum & Maximum \\
\hline Clay $\left(\mathrm{g} \mathrm{kg}^{-1}\right)$ & 118 & 23.2 & 80 & 170 \\
\hline Sand $\left(\mathrm{g} \mathrm{kg}^{-1}\right)$ & 758 & 67.2 & 610 & 880 \\
\hline Silt $\left(\mathrm{g} \mathrm{kg}^{-1}\right)$ & 125 & 51.3 & 40 & 240 \\
\hline pHwater & 5.8 & 0.4 & 4.9 & 6.7 \\
\hline$C\left(\mathrm{~g} \mathrm{~kg}^{-1}\right)$ & 5.2 & 1.5 & 3.2 & 8.6 \\
\hline $\mathrm{N}\left(\mathrm{g} \mathrm{kg}^{-1}\right)$ & 0.4 & 0.08 & 0.33 & 0.66 \\
\hline$P\left(\mathrm{mg} \mathrm{kg}^{-1}\right)$ & 7.57 & 7.8 & 1.3 & 94.2 \\
\hline $\mathrm{Ca}\left(\mathrm{cmol} \mathrm{kg}^{-1}\right)$ & 1.86 & 0.7 & 0.75 & 16.6 \\
\hline $\mathrm{Mg}\left(\mathrm{cmol} \mathrm{kg}^{-1}\right)$ & 0.36 & 0.25 & 0.1 & 1.45 \\
\hline $\mathrm{K}\left(\mathrm{cmol} \mathrm{kg}^{-1}\right)$ & 0.19 & 0.06 & 0.1 & 0.3 \\
\hline $\mathrm{ECC}\left(\mathrm{cmol} \mathrm{kg}^{-1}\right)$ & 3.3 & 1.9 & 2 & 6.7 \\
\hline $\mathrm{Zn}\left(\mathrm{mg} \mathrm{kg}^{-1}\right)$ & 14.6 & 6.06 & 5.1 & 31.1 \\
\hline $\mathrm{Fe}\left(\mathrm{mg} \mathrm{kg}^{-1}\right)$ & 28.5 & 27.7 & 8.1 & 125.4 \\
\hline
\end{tabular}

\section{Previous Land use Before Rice Cropping}

Herbaceous cultivar of cowpea (Vigna unguiculata (L) Wap. unguiculata) locally named "tontouin" were used by all the farmers. It is a short duration matured cultivar of 65-70 days cycle. Every year, early in April, 2 plots of $5 \mathrm{~m} \times 10 \mathrm{~m}$ were choose randomly in farmers' field for cowpea cropping. After manual cleaning and tillage, the cowpea was sown per hill of 2 grains in dimensions of $30 \mathrm{~cm} \times$ $60 \mathrm{~cm}$. The hand weeding was applied at 21 and 45 days after emergency. At maturity, the cowpea was harvested and plant residues were left in the field, sundried during a week and incorporated to the soil during the tillage operation for rice seeding. In the meantime, two other plots of $5 \mathrm{~m} \times 10 \mathrm{~m}$ occupied exclusively by bush (dominated by Rottboellia cochinchinensis, Digitaria horizontalis, Ageratum conyzoides and Tridax procumbens, Imperata cylindica, cyperus spp) were cleaned and the native grass residues were also incorporated into the soil.

\section{Rice Plots}

Early in June of every year of experiment, cowpea and grass residues were incorporated in the soil of their respective growing plots of $5 \mathrm{~m} \times 10 \mathrm{~m}$ dimensions. A completely randomized blocks design was applied using a local rice variety named Ina Okpè (V1) and NERICA 1 (V2) rice variety. Each rice variety was sown in a plot previously occupied by legume and bush fallow. Rice was sown at 3 grains per hill spaced by $20 \mathrm{~cm} \times 20 \mathrm{~cm}$ ten days after residues incorporation. Hand weeding was applied at 21 and 45 days after emergency. At maturity, the rice was harvested, sundried before threshing. The grain yield was calculated for standard moisture content of $14 \%$.

\section{Studied Treatments}

Two cropping systems were considered including rotation of cowpea-rice (Syst-1) and bush-rice (Syst-2) within the same cropping season. Two cultivars named Ina Okpè and NERICA1 were respectively noted V1 and V2 for the experiment. Therefore, four treatments were defined as T1 (Syst-1 + V1), T2 (Syst-1 + V2), T3 (Syst-2 + V1) and T4 (Syst-2 +V2).

\section{Soil Sampling and Laboratory Analysis}

Soil samples were taken in $0-20 \mathrm{~cm}$ depth of soil in each corner and the center of treatment plots (T1, T2, T3 and T4). The five samples were mixed before taking for a composite sample of soil in a given treatment before the experiment in 2001. A sample was taken from each treatment plot in all the location of experiment. Similar operations were done in 2002 before the second experiment. The composite samples were dried, ground and sieved $(2 \mathrm{~mm})$ before the laboratory analysis was carried out. Soil pHwater (1: 2.5) and soil contents in Carbone-C (Wakley and Black), total nitrogen-N (Kjeldahl), P (Bray I), K, Ca, Mg and Zn (1 N NH4OAc $(\mathrm{pH}$ 7.0)) were determined as described by American Society of Agronomy-ASA and Soil Sciences Society of America-SSSA [22].

\section{Statistical Analysis}

By descriptive statistic, mean value of soil nutrient contents, the minimum and maximum values as well as the standard deviation were determined in 2001 before the experiment. A mixed model analysis was used to calculate the difference (2001-2002) of nutrient content in the soil of a given treatment from 2001 to 2002. By the same method, the balances of cation contents (2001-2002) were determined between treatments. The balances of $\mathrm{C}, \mathrm{N}, \mathrm{P}$ and $\mathrm{K}$ contents were also determined by mixed model within the same plot from 2001 to 2002.

Analysis of variances was use to determine mean values of rice grain yield for each cultivar (V1 and V2) in a given cropping system (Syst-1 and Syst-2) and for each treatment (T1, T2, T3 and T4). Pearson correlation was performed to evaluate the relationship between nutrients and rice grain yield. These analysis were done for $a=0.05$ with SAS software.

\section{Results}

\section{Soil Status}

[Table-2] is showing the changes in soil C, N, P and $\mathrm{K}$ contents according to the difference between treatments from 2001 to 2002. No significant $(P>0.05)$ effect of treatments was observed on soil 
nutrient content at $a=0.05$. Nevertheless, treatment effect could be observed on organic $C$ content in soil at $a=0.10(P=0.08)$. More organic $\mathrm{C}$ content was noticed for T4 than T1 and T3 at this significant level. But, the difference observed between T2 and T4 was not significant at all.

Table 2- Differences of soil contents in C,N,P and $\mathrm{K}$ between different treatments (T1,T2, T3 and T4) before the experiment of 2002

\begin{tabular}{|c|c|c|c|c|}
\hline Treatments & $\mathrm{C}\left(\mathrm{g} \mathrm{kg}^{-1}\right)$ & $N\left(g_{k g}^{-1}\right)$ & $P\left(\mathrm{mg} \mathrm{kg}^{-1}\right)$ & $\mathrm{K}\left(\mathrm{cmol} \mathrm{kg}^{-1}\right)$ \\
\hline T1 - T2 & -0.065 & 0.025 & -0.677 & 0.004 \\
\hline T1 - T3 & 0.053 & 0.006 & -1.599 & -0.01 \\
\hline T1 - T4 & $-0.916^{\star * *}$ & 0.002 & -0.617 & -0.005 \\
\hline $\mathrm{T} 2-\mathrm{T} 1$ & 0.061 & 0.025 & 0.677 & -0.004 \\
\hline T2 - T3 & 0.119 & 0.032 & -0.883 & -0.014 \\
\hline $\mathrm{T} 2$ - T4 & -0.851 & 0.023 & 0.059 & -0.008 \\
\hline $\mathrm{T} 3-\mathrm{T} 1$ & -0.053 & -0.006 & 1.599 & 0.01 \\
\hline T3 - T2 & -0.119 & -0.032 & 0.882 & 0.014 \\
\hline T3 - T4 & $-0.970^{\star \star *}$ & -0.009 & 0.942 & 0.005 \\
\hline $\mathrm{T} 4$ - T1 & $0.916^{\star * *}$ & 0.002 & 0.617 & 0.005 \\
\hline $\mathrm{T} 4$ - T2 & 0.851 & -0.023 & -0.059 & 0.008 \\
\hline T4 - T3 & $0.970^{* * *}$ & 0.009 & -0.942 & -0.005 \\
\hline $\mathrm{Pr}>\mathrm{F}$ & 0.08 & 0.518 & 0.574 & 0.523 \\
\hline
\end{tabular}

***:highly significant

[Table-3] is showing the difference of soil nutrient contents from 2001 to 2002 according to a given treatments. Significant depressed $\mathrm{N}$ contents were observed in $\mathrm{T} 1\left(0.01 \mathrm{~g} \mathrm{~kg}^{-1}\right)$ and $\mathrm{T} 2$ $\left(0.009 \mathrm{~g} \mathrm{~kg}^{-1}\right)$. Similar effects were observed respectively for T3 and T4. It is also observed significant decreased of soil content in Ca $\left(1.39 \mathrm{cmol} \mathrm{kg}^{-1}-1.67 \mathrm{cmol} \mathrm{kg}^{-1}\right)$ for all the studied treatments. Only the treatment T3 has induced significant decreased of soil content in Mg from 2001 to 2002. Potassium content in soil was also significantly decreased in treatments T2 and T3 indifferently to cultivars and previous land occupation. Zinc contents in soil on 2002 were decreased in all the treatments in opposite to Fe contents which were increased from 2001 to 2002 according to the negative values observed for the differences.

Table 3- Chemical changes in soil (2001-2002) of each treatment from 2001 to 2002

\begin{tabular}{|c|c|c|c|c|}
\hline & \multicolumn{4}{|c|}{ Difference (2001-2002) } \\
\hline & $\mathrm{T} 1$ & $\mathrm{~T} 2$ & T3 & T4 \\
\hline $\mathrm{Ph}$ & $-0.046 n s$ & $0.100 n s$ & $0.012 n s$ & $-0.082 n s$ \\
\hline$C\left(g_{k g}^{-1}\right)$ & $0.580 n s$ & $1.960 n s$ & $2.191 n s$ & $0.438 n s$ \\
\hline$N\left(g_{k g}^{-1}\right)$ & $0.010^{* * *}$ & $0.009^{* * *}$ & $0.014^{* \star *}$ & $0.009^{* * *}$ \\
\hline$P\left(\mathrm{mg} \mathrm{kg}^{-1}\right)$ & Ons & Ons & Ons & Ons \\
\hline $\mathrm{Ca}\left(\mathrm{cmol} \mathrm{kg}^{-1}\right)$ & $1.42^{* \star *}$ & $1.55^{* * *}$ & $1.676^{* * *}$ & $1.396^{* * *}$ \\
\hline $\mathrm{Mg}\left(\mathrm{cmol} \mathrm{kg}^{-1}\right)$ & $0.05 n s$ & $0.119 n s$ & $0.229^{* *}$ & $0.135 n s$ \\
\hline $\mathrm{K}\left(\mathrm{cmol} \mathrm{kg}^{-1}\right)$ & $0.028 n s$ & $0.068^{* *}$ & $0.041^{*}$ & $-0.0002 n s$ \\
\hline $\mathrm{Zn}\left(\mathrm{mg} \mathrm{kg}^{-1}\right)$ & $9.772^{\star * *}$ & $8.459^{* * *}$ & $9.845^{\star * *}$ & $9.899^{* * *}$ \\
\hline $\mathrm{Fe}\left(\mathrm{mg} \mathrm{kg}^{-1}\right)$ & $-132.18^{\star * *}$ & $-145.3^{* \star *}$ & $-125.53^{\star \star *}$ & $-132.22^{\star * *}$ \\
\hline
\end{tabular}

ns: not significant; *: significant; **: highly significant; ***: very high significant

\section{Rice Yield}

[Table-4] shows the coefficient $(R)$ values of Pearson correlation between rice grain yield obtained in 2001, and soil nutrients content, particularly the cations ( $\mathrm{Ca}, \mathrm{Mg}, \mathrm{K}, \mathrm{Zn}$ and $\mathrm{Fe}$ ) in 2002 , before the second trial. Significant $(P<0.05)$ R-value of 0.38 was observed between $\mathrm{K}$ content in soil and rice grain yield obtained in the treatment $\mathrm{T} 2$. The treatment $\mathrm{T} 3$ has also induced a significant positive $\mathrm{R}$-value (0.41) between soil content in $\mathrm{Ca}$ and rice grain yield recorded. In opposite, in the same treatment (T3), significant negative $R$ value $(-0.57)$ was observed between soil content in Fe and rice grain yield. No significant relationship was observed in treatments $\mathrm{T} 1$ and $\mathrm{T} 4$ respectively related to legume crop and bush fallow as precedent of rice.

Table 4- $R$ values of Person correlation between rice grain yield and soil content in cations ( $\mathrm{Ca}, \mathrm{Mg}, \mathrm{K}, \mathrm{Zn}$ and $\mathrm{Fe}$ ) for each treatment in 2002

\begin{tabular}{|c|c|c|c|c|}
\hline \multicolumn{5}{|c|}{ Coefficient (R) } \\
\hline Nutrients & $\mathrm{T} 1$ & T2 & T3 & T4 \\
\hline $\mathrm{Ca}$ & -0.141 & 0.139 & $0.410^{\star *}$ & 0.185 \\
\hline $\mathrm{Mg}$ & 0.079 & -0.055 & 0.132 & 0.213 \\
\hline K & -0.109 & $0.386^{*}$ & 0.321 & 0.039 \\
\hline $\mathrm{Zn}$ & -0.235 & 0.181 & 0.579 & 0.065 \\
\hline $\mathrm{Fe}$ & 0.285 & 0.019 & $-0.576^{\star \star \star}$ & 0.164 \\
\hline
\end{tabular}

*: significant; **: highly significant; ${ }^{* * *}$ : very high significant

[Fig-1] shows the grain yield harvested for both rice cultivars in the two cropping systems including cowpea (Syst-1) and native grass (Syst-2) as precedent of rice respectively. In Syst-1 and Syst-2, rice grain yields were significantly higher for V2 (NERICA 1) than V1 (Ina Okpè). Moreover, the yields observed in Syst-2 were lower than those in Syst-1. This result was confirmed by [Fig-2] showing significantly $(P=0.002)$ higher average rice grain yield for Syst-1 (1.41 tha-1).

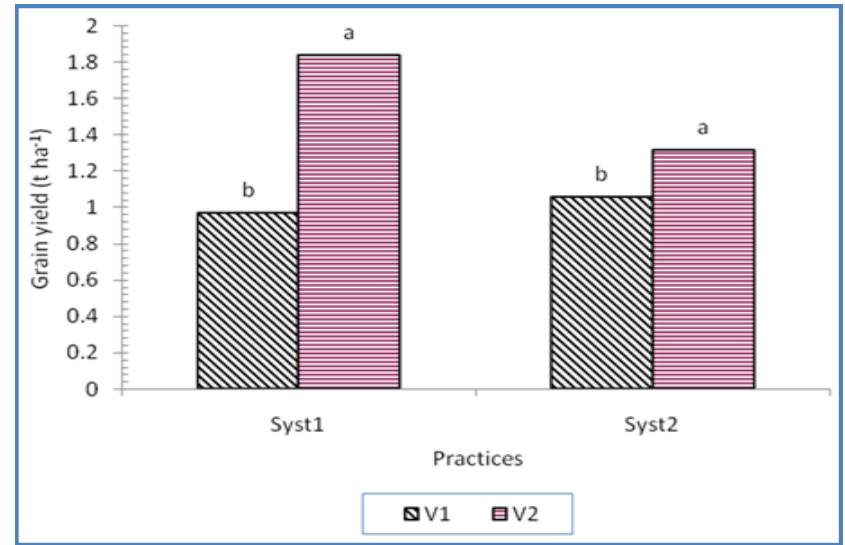

Fig. 1- Average grain yield significantly $(P<0.05)$ obtained for each cultivar in the two different studied systems

(Syst-1= legume incorporation in soil; Syst-2 = grass incorporation in soil; V1 = Ina Opke, V2= NERICA1).

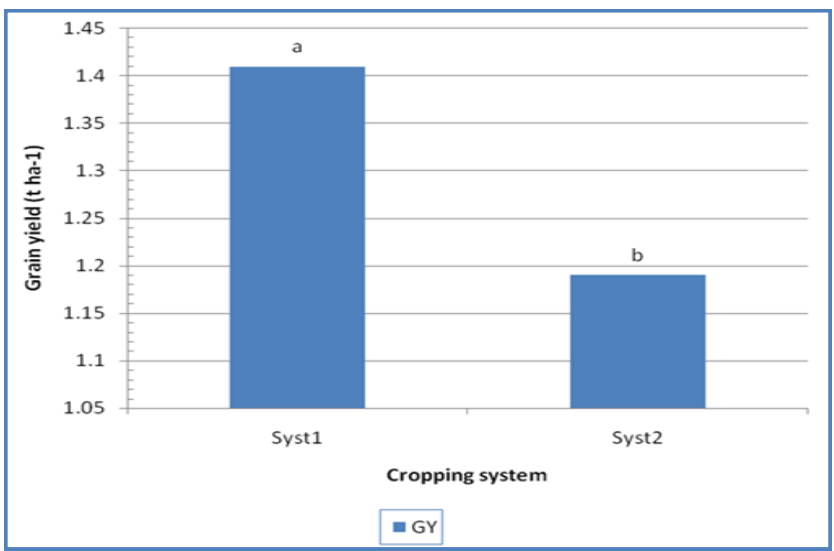

Fig. 2- Average rice grain yield observed $(P=0.002)$ by cropping system (Isd was 0.13 t ha-1) 
Lower correlation coefficient $(R)$ values were observed between cropping system and grain yield than the one observed with cultivar [Table-5]. The coefficient values were also significantly negative with the cropping system while they were positive with cultivar. Increasing values of $R$ were observed from 2001 to 2002 for Syst ($0.10 ;-0.34)$ and cultivar $(0.50 ; 0.66)$. Across year mean values indicated significant $(P<0.0001)$ higher value of correlation coefficient (0.61) for cultivar while, -0.24 was noticed studied systems (Syst).

Table 5- Coefficient ( $R$ ) of Pearson correlation between rice grain yield and the cropping system as well as the cultivar in 2001 and 2002 likewise across year.

\begin{tabular}{|c|c|c|c|}
\hline & & System & Cultivar \\
\hline \multirow{2}{*}{2001} & $R$ value & -0.1 & 0.57 \\
\hline & $P>|r|$ & 0.03 & $<0.0001$ \\
\hline \multirow{2}{*}{2002} & $R$ value & -0.34 & 0.001 \\
\hline & $P>|r|$ & 0.66 & $<0.0001$ \\
\hline \multirow{2}{*}{ Mean } & $R$ value & -0.24 & 0.002 \\
\hline & $P>|r|$ & 0.61 & $<0.0001$ \\
\hline
\end{tabular}

Significant difference was observed between mean values of grain yields obtained according to treatments as illustrated in [Fig-3]. In 2001 and 2002, the lowest yields were respectively observed in T1. The treatment T3 has also induced similar lower yield in 2002. The highest yields are observed invariably in T2 every year of the experiment. Moderate rice yield was observed in T4 in 2001 and 2002.

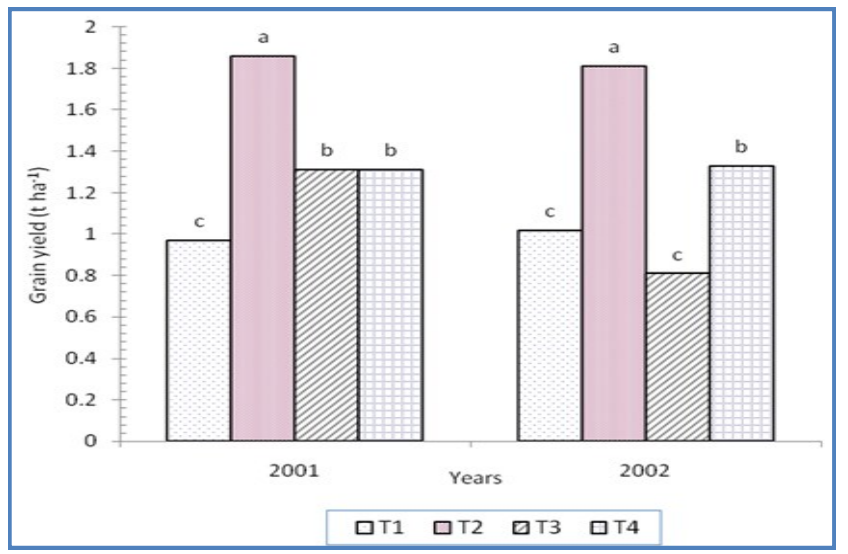

Fig. 3- Rice grain yield induced by each treatment in 2001 and 2002

\section{Discussions}

\section{Cropping System Effects in the Soil}

Exclusive application of organic matter as fertilizer should be considered according to soil chemical status. Infact, nutrients released by organic matter can be slow depending on temperature, oxygen supply, soil moisture, hydrogen ion concentration and inorganic nutrient contents, $\mathrm{C} / \mathrm{N}$ ratio of the mulched organic matter [19]. This situation can impaired crop nutrition because of delay in nutrients supplying. Therefore, inherent fertility level of soil is an essential contribution for the success of this technology. Moreover, crop response to exclusive organic fertilizer was known to be far below the satisfaction level required to meet word food need [14]. Thus, it is required a minimum chemical fertilizer in association with organic matter for well amendment of agricultural soil. Minimum $\mathrm{N}$ and $\mathrm{P}$ were also required for cowpea growing and biological N2 fixation in soil $[2,24]$ in order to improve yield and biological amendment of soil. Therefore, the use of cowpea as preceding crop to rice without fertilizer on a poor soil in $\mathrm{N}$ and $\mathrm{P}$ could not affect significantly nutrients balance in a positive way as observed in the soil of actual study. Consequently, soil nutrient contents were depleted after rice cropping in 2001, especially, for soil C content [Table-2]. In addition to the low organic matter production by cowpea [8], there is a loss of about $78 \%$ of initial cowpea $\mathrm{C}$ from the incorporation period to the end of the rainy season [12]. This can explain the restriction of soil organic $C$ builds up in our study. The treatment including native grass incorporation and NERICA1 has the highest $\mathrm{C}$ content, probably, because of a low mineralization rate of this organic matter.

From 2001 to 2002, there was a possibility of $P$ release up to 7.57 $\mathrm{mg} \mathrm{kg}^{-1}$ according to the null value of $P$ balance in the soil of all the treatments. Therefore, the incorporation of vegetal residue as cowpea or native grass can supply sufficient $P$ to soil for rainfed rice production but cannot restore the fertility of soil. In fact, it has been reported that legumes incorporation can improve bioavailability of sparingly soluble soil $\mathrm{P}[30$ ] and organic matter did so for native $P$ in soil [28]. Thus we conclude that the incorporation of cowpea or native grass residues can prevent from $P$ content depletion in acid soil. The effect native grass of $P$ as observed in actual study is an essential finding that can help in management of agricultural land in tropical zone where P-deficient in acid soil in among the major limiting factors [18].

In all the studied treatments, decreasing of $\mathrm{Ca}$ and $\mathrm{Zn}$ contents were observed after rice growing in 200, but Fe contents were increased. This results as two implications: incorporation of plant residues i) can help to correct Fe-deficient occurring in upland rice as chlorosis (rain-induced scorching), ii) increasing soil Fe content in upland can provoke contamination of lowland throughout runoff creating iron toxicity that is also a serious threat of rice [11]. From this analysis, we assert that the studied technology should be recommended for foot slope ecology because to limit the possible enrichment of subsequent lowland soil in $\mathrm{Fe}$.

\section{Adoption of Biological and Organic Fertilization in Rice-based Systems}

Cowpea as preceding crop of rice has induced highest grain yield compared to the grass fallow in a proportion of $16 \%$. Although this result is highly significant, the output of such study should depend on the nature of spontaneous, because of the variability of plant residue content in nutrients as describe by Tian [29]. Infact, some species like Chromolaena Odorata was known to have excellent effects on most of rice growth parameters and yield when their residues were incorporated into soil [17]. However, most of the grass growing cycle occupied all the cropping season, hampering a second cropping within the same land. The growth and incorporation of legume crops are therefore recommended as green manure in ranfed area for subsequent crops [3,23] as they can grow within a short time. Variance of actual result can also be observed depending on cowpea cultivar abilities for well nodulation [13] and their maturity cycle (biomass production). Indeed, Schulz, et al. [26] showed that aboveground residue dry matter increases with the maturity class of the cowpea. In the studied ecology where the raining season occurred from April to October, the cowpea should be early matured cultivar (70 days) to ensure the subsequent rice 
cropping during 70-90 days. In such conditions, Dakora, et al. [9] suggested a rapid incorporation of cowpea residues before rice sowing in order to improve the suitability of this technology. Howev$\mathrm{er}$, the rice grain yield of $1.6 \mathrm{t} \mathrm{ha}^{-1}$ induced by cowpea as previous crop is closed to the yield observed under the use of chemical fertilizers in South Benin on Acrisol while, about 3 tha $^{-1}$ were harvested in the Centre Benin on Ferralsol Ferric [15]. Therefore, the use of cowpea as preceding crop in rice-base systems is more relevant to the ecological zone as South Benin where the technology will not induce a yield gap. The actual study revealed that interspecific upland rice as NERICA1 can be use successfully for this.

To enhance rice production in the Centre Benin by this technology, it should be recommended the application of minimum chemical fertilizer in order to improve $\mathrm{N}$ fixation ability et dry matter production of cowpea. In fact, the low fertility of the studied soil could affect these parameters [7] reducing the benefit to the subsequent rice.

\section{Conclusion}

The study has revealed the interspecific cultivar-NERICA1 as more relevant for bio- and organic fertilizer on acidic plinthosol. The use of grain legume as preceding crop and organic source of nutrients was better than grass fallow practice. However, the thechnology has low benefit to soil and induced rice yield was limited as much as on Acrisol in bimodal rainfall ecology.

Because of the increased of soil content in Fe and the yield observed, this technology was recommended for bimodal rainfall excluding the soil on foot slope to avoid potential iron toxicity of rice in the subsequent lowland.

Applying minimum chemical fertilizer to cowpea was recommended for improving the impact of the technology for soil and rice yield in plinthosol under monomodal rainfall ecology.

\section{Reference}

[1] Ali M. (2004) Tropical Pulse Crops, In World Fertilizer Use Manual, Ed. International Fertilizer Industry Association, 5.

[2] Amadji L.G., Koné B., Aholoukpé H.N.S. (2007) J. Rech. Sci. Univ. Lomé (Togo), A9(2), 109-120.

[3] Becker M., Ladha M.K., Ali M. (1995) Plant Soil, 174, 181-194.

[4] Becker M. and Johnson D.E. (1998) Biology and Fertility of Soils, 27, 358-367.

[5] Becker M. and Johnson D.E. (1999) Nutrient Cycling in Agroecosystems, 53, 71-81.

[6] Buresh R.J., Smithson P.C. and Hellums D.T. (1997) SSSA Special Publication, 51, SSSA, Madison, WI, USA.

[7] Carsky R.J., Singh B.B., Oyewole B. (2001) Biological Agriculture and Horticulture, 18, 303-315.

[8] Carsky R.J., Vanlauwe B., Lyasse O. (2002) World Cowpea Conference III held at the International Institute of Tropical Agriculture (IITA), Ibadan, Nigeria, IITA, Ibadan, Nigeria.

[9] Dakora F.D., Aboyinga R.A., Mahama Y., Apaseku J. (1987) MIRCEN Journal, 3, 389-399.

[10]Dingkuhn M., Jones M.P., Johnson D.E., Sow A. (1998) Field Crops Research, 57, 57-69.
[11]Dufey I., Hiel M.P., Hakizimana P., Draye X., Lutts S., Koné B., Dramé K.N., Konaté K.A., Sié M., Bertin P. (2012) Crop Sci., 52, 539-550.

[12]Franzluebbers K., Juo A.S.R., Manu A. (1994) Plant and Soil 166, 255-265.

[13]Giller K.E. (2001) Nirogen Fixation in Tropical Cropping Systems, 2nd ed., CAB International, Wallingford, UK.

[14]Hiyami Y. and Ruttan V. (1985) Agricultural Development: An International Perspective., John Hopkins Univ. Press, Baltimore, MD.

[15]Koné B., Amadji G.L., Igué M., Ayoni O. (2009) Jounal of Animal and Plant Science, 2(4), 156-162.

[16]Koné B., Yao-Kouamé A., Sorho F., Diatta S., Sié M., Ogunbayo A. (2010) Int. J. Biol. Chem. Sci., 4(3), 563-570.

[17]Koné F., Kouadio J.Y., Yapo E.S., Visser M. (2010) Journal of Applied Sciences Research, 6(11), 1581-1588.

[18]Koné B., Oikeh S., Diatta S., Somado A., Kotchi V., Sahrawat K.S. (2011) Arc. of Agronomy and Soil Science, 57(4), 421-32.

[19]Kumar R., Reddy R.M., Sinha P.S., Tirkey J., Singh M.K., Prasad B.C. (2010) Journal of Entomology, 7(4), 219-226.

[20]Oikeh S.O., Nwilene F., Diatta S., Osiname O., Touré A., Okeleye K.A. (2008) Agronomy Journal 100 (3), 735-741.

[21]Oikeh S., Houngnandan P., Robert A., Niang A., Toure A., Koné B. (2010) Journal of Agricultural Science and Technology $4(1-26), 54-61$.

[22]Page A.L., Miller R.H. and Keeney D.R. (1996) Methods of Soil Analysis, Chemical and Microbiological Properties, Part-2, ASA Monograph, 9, 2nd ed., American Society of Agronomy, USA.

[23]Rafael M., Navarro C., Ariza D., Gonzalez L., Campo A., Arjona M., Ceacero C. (2009) Soil Tillage Res., 102, 38-44.

[24]Sanginga N., Lyasse O., Singh B.B. (2000) Plant and Soil, 220, 119-128.

[25]Sanginga N., Dashiell K.E., Diels J., Vanlauwe B., et al. (2003) Agriculture Ecosystems Environment, 100, 305-314.

[26]Schulz S., Carsky R.J. and Tarawali S. (2001) Soil Fertility Maintenance in West Africa, ASA, Madison WI.

[27]Somado E.A., Becker M., Kuehne R.F., Sahrawat K.L., Vlek P.L.G. (2003) Agronomy Journal, 95, 1172-1178.

[28]Tandon H.L.S. (1987) Fertilizer Development and Consultation Organization, New Delhi, India.

[29]Tian G. (1992) Biological Effects of Plant Residues with Constrasting Chemical Compositions on Plant and Soil under Humid Tropical Conditions, PHD Thesis, Wageningen Agricultural University, Pays-Bas.

[30]Vanlauwe B., Diels J., Sanginga N., Carsky R.J., Deckers J., Merckx R. (2000) Soil Biology and Biochemistry., 32, 20792090.

[31]Vanlauwe B., Aihou K., Aman S., Iwuafor E.N.O., Tossah B.K., Diels J., et al. (2001) Agronomy Journal, 93, 1191-1199. 